\title{
Integrated Knowledge at State Islamic University of North Sumatra (UINSU), Medan, Indonesia
}

\author{
Nur Aisah Simamora \\ Ph.D Student at State University of North Sumatra (UINSU), Medan, Indonesia \\ Lecturer at Ushuluddin Faculty, State University of North Sumatra (UINSU), Medan, Indonesia
}

\begin{abstract}
Islam teaches that all human-developed knowledge branches are completely integrated with the Knowledge of Owner, al-'Alim, the All-Knowing, integrated with all creatures and the universe. This knowledge (al-'ilm) is one of the eternal natures of God.In Islamic epistemology, knowledge consists of two categories; theoretical (al-fiqhu al-akbar) and practical (al-fiqhu al-ashghar).Islamic universities in Medan City, especially UINSU Medan majority are still formalists with various levels; Philosophical, material, and strategic. If the formalist model of knowledge integration is continuously allowed, it will eventually lead to secularism, because the public will come to the conclusion that God, morals, spiritual souls are only in educational institutions which are Islamic labeled. As for educational institutions that are not Islamic labeled, there will be found knowledge that is not Islam, paganism, no God, no morals, and so on, in fact all the knowledge belongs to Allah and comes from Allah SWT.
\end{abstract}

Keywords: Al Quran; integrated knowledge; universities; UINSU

\section{INTRODUCTION}

Islam teaches that all human-developed knowledge branches are completely integrated with the Knowledge of Owner, al-'Alim, the All-Knowing, integrated with all creatures and the universe. This knowledge $($ al-'ilm $)$ is one of the eternal natures of God. This knowledge is absolute and encompasses the whole of existence and the universe, even the source of all things. Since knowledge itself is the eternal, holy, and universal natures of God, then all knowledge come from Him, so God is the only source of knowledge. God is the First Grand Master from whom the light of knowledge (light of knowledge, nur al-'ilmi) emanates with His compassion. ${ }^{1}$

The integration concept of Nur Ahmad FadhilLubiswhich is understood by the researcher, either through his explanations in workshops or seminars held by POKJA Akademik IAIN Sumatera Utara throughout the year 2013 - which took the model of integration with trans-disciplinary term; Namely: a study of science with the review and theory of various sciences (trans-discipline), until finally emerged a new ijtihad. It means he wants to say that the integration model of such knowledge will be found unity and interrelationship with one kind of knowledge with another kind, and next, will be formulated a new knowledge that is different from some kinds of trans-disciplined knowledge, so the result will display the face of Islam which is solution to the human contemporary problems, as well as from the books he wrote as a guide for UIN SU academics to implement the integration (read: basic and objectives) model that will be applied in UIN SU.

In other words, he wanted to explain that for the contemporary context, knowledge cooperation is urgently needed to overcome all human contemporary problems. Nevertheless, UIN SU should not abandon its identity as the center of Islamic studies. The meaning is UIN SU must ensure that in the future Islamic studies such as Ushuluddin, Da'wah, Shariah, and Tarbiyah must continue to grow, even more advanced than what is achieved today. The principleused is al-muhâfazah al-al-qadîm ash-shâlihwa al-akhzu bi al-jadîd al-ashlah (maintaining the old tradition of being good and taking the new better things). ${ }^{2}$

The research that will be conducted by the researcher is different from those that have been stated above and more actual-today-especially in welcoming the conversion of IAIN North Sumatra into UIN, because researcher will more discuss the application of the integration concepts at several Islamic universities in Medan City, where fundamentally, the ideas about the integration concept have long been heard and emerged in North Sumatra. For that reason, the researcher considers it is important to know the concrete process of ideas that have

\footnotetext{
${ }^{1}$ Syahrin, integrasi..., p. 8.

${ }^{2}$ Nur A. FadhilLubis , RekonstruksiPendidikanTinggi Islam; MemberiMaknaKelahiran UINSU. (Bandung: Citapustakamedia, 2014), p. v.
} 
emerged, as well as how far the concepts have been applied in various Islamic educational institutions in Medan City. Especially considering the close proximity of IIUM in Malaysia that has implemented an integration model in collaboration with IIIT in the region of North Sumatra, where the region of Sumatera should more quickly follow and imitate the model of the higher education.

\section{METHODOLOGY}

MulyadhiKartanegara listed in his book that Muslim philosophers agree to say that the purpose of studying is to gain happiness. Of course the knowledge meant above is the studies with their implications on the practical level. In another words, the study that delivers the person into an enlightened personality of his life, makes him able to distinguish the good from the bad things, can illuminate his way of life, even the way of many people's life.In Islamic epistemology, knowledge consists of two categories; theoretical (al-fiqhu alakbar) and practical (al-fiqhu al-ashghar). Several figures have different opinions in assessing which of them is more urgent for its existence. But most figuresincluding MulyadhiKartanegara see that the position and urgency of both categories of knowledge are the same. ${ }^{3}$

The philosophers make the two categories of knowledge above are accordance to human'mind which is also divided into two classifications; theoretical and practical minds. Although both have the same meaning of minds, but they have fundamental differences; theoretical mind possesses the theoretical objects of knowledge in the form of physical or non-physical entities, with the main task is establishing a comprehensive knowledge scientific building, and the object of practical mind knowledge is the free action of man with the primary task is managing the human passions or as a manager (mudabbir). ${ }^{4}$ Although the theoretical and practical knowledge or mind can be distinguished by the object and the task, but both cannot be separated in their understandings, because it will affect the disintegration in understanding it. If the disintegrating understanding develops, then one branch of knowledge will deviate from its main function and purpose. In other words, the intended integration between theoretical and practical knowledge is the integration in understanding it; the explanation of the concept must begin from the theoretical-metaphysical foundation, and next to the stage of application. So he reiterated the necessity of integration between these two knowledge: "Why does Alfarabi's political book, for example, not explain the topics that relevant to the politics directly, but instead start with a fairly long discussion of metaphysics, because practical knowledge isnone other than the application of theoretical knowledge. ${ }^{5}$

Amin Abdullah is one of the thinkers in Indonesia who initiated the idea of knowledge integration. There are three stages that have been passed in the exploration of his thoughts to arrive at the maturity of thinking about the knowledge integration. His first book entitled "Studi Agama: NormativitasatauHistorisitas?" where he explains that religious studies (ilmu-ilmu agama) must begin to be approached or discussed by using normative and historical approaches. The goal is to establish the right relationship and will be halfway in an effort to reduce the tension between the two approaches, so that the results or the conclusions of a knowledge branch are not necessarily absolute normative or otherwise profane and historic, or even to negate the existence of others and eliminate the benefits value inherent in the knowledge approach that each scientific tradition possesses.

According to Amin Abdullah, the relationship between two historical and normative approaches should not take a face-to-face and dichotomous. The relationship between the two is like a coin with two surfaces, where the relationship between the two coin surfaces cannot be separated, but firmly and clearly distinguishable. The relationship between the two is not like two stand-alone entities that face each other, but both are woven, intertwined, and knitted in such a way; so that they are integrated into a solid and compact unity. ${ }^{6}$

Amin Abdullah's second book -as the development of the idea of knowledge integration- entitled "Islamic Studies di PerguruanTinggi; PendekatanIntegratif-Interkonektif". The paradigm of knowledge integration offered is not a merging normative and sacred model into the historic and the profane, nor vice versa immersing the historical into the normative-sacred. However, he offers an interconnectiveknowledge paradigm, in which he assumes that the complexity of life's problems experienced and confronted by modern humans requires for any knowledge (including Islamic studies and other religions), social study, humanities, as well as the natural sciences to cooperate, mutual greeting, mutual need, mutual correction, and interconnected, so that every knowledge branch can solve every problem of life that appears in the field. Any knowledge cannot stand on its own, and when it claims that it can, thinks able to solve problems on its own, and does not require

\footnotetext{
${ }^{3}$ Ibid.,p. 163 .

${ }^{4}$ Ibid.

${ }^{5}$ Ibid.,p. 164.

${ }^{6}$ M. Amin Abdullah, Studi Agama: NormativitasatauHistorisitas?,cet. Ke V. (Yogyakarta: PustakaPelajar, 2011), p. Viii-viii.
} 
donations from other knowledge, this self-sufficiency sooner or later will turn into narrow mindedness not to call it as the particularity fanaticism of knowledge discipline. ${ }^{7}$

The interconnectivity paradigm offered by Amin Abdullah tries to establish relationships between various knowledge disciplines, in order to be more open and melt the blocks and boundaries between the culture of supporting of religious studies which source from the texts (hadhârat an-nash), and the culture of supporting of factual-historical-empirical study(social sciences and natural sciences) or termed by hadhârat al-'ilm, as well as cultural supporters of ethical-philosophical scholarship (hadhârat al-falsafah).

The researcher analysis finds that there is a similarity between the integration model offered by MulyadhiKartanegara and Amin Abdullah, where both offer a model of knowledge integration that cannot be separated from one another, even if theoretical and practice knowledge can be distinguished by its object and task, but both cannot be separated, because it will result in disintegration. According to Amin Abdullah, in the order of each objects and tasks of theoretical and practical knowledge can be distinguished, this is called interconnection, but in understanding the knowledge holistically, they cannot be separated, and this is called integration. This is because the applied or practical studies that have been created by Muslim philosophers always have a theoretical foundation, especially their metaphysical foundation. In this case, there is a point of similarity between the integration concept initiated by Amin Abdullah and MulyadhiKartanegara, although Amin Abdullah adds the term of integration-interconnection.

Kuntowijoyo sees that the integrative knowledge has the main prerequisites, namely:building the knowledge with a philosophy of knowledge base that can accommodate all kinds of knowledge. The philosophy meant here must have clear views and concepts on the existing reality, because such views are the keys to the development of knowledge. Kuntowijoyo mentions that we will never see the world directly, and we are only able to see the world through the paradigm. We also can never see the world as a whole, and we can only see it in fragments, snap shots. For this reason, the needed philosophy of knowledge is a philosophy that can clearly describe a paradigm that can create a specific framework of thinking, methodology and specific axiology. ${ }^{8}$ The existence of disintegration in the world of knowledge, then it requires an integration or re-integration of knowledge, the following is a category or model of re-integration that developed in Islamic educational institutions:

\section{A. Formalist Integration}

The formalist integration is an effort of knowledge integration which is pursued formally at the level of concept, labeling the name of educational institution with the word "Islam", the name of the faculty and study program, or at the level of the material or course, either in the form of specific books specifically for all majors, using ayat (verses) and hadith in every course. In general, the research finds that the average integration model for Islamic universities in Medan City is formalist with various levels, either at philosophical level, material level, and strategic level. One forms of material level is the effort of using ayat and hadithin almost all Islamic universities found and applied, although they are not maximized. It is found in Universitas Islam Sumatera Utara (UISU), UniversitasMuhammadiyah Sumatera Utara (UMSU), Universitas al-Washliyah (UNIVA), and UniversitasPanca Budi (UNPAB).

\section{B. Substantive Integration}

Substantive integration is an effort of knowledge integration at philosophical level, in which the institution specifically does not label itself with the word "Islam", but in its application, Islamic valuesare taught and implemented. This substantive integration model also has levels, philosophical, material and strategic. At the philosophical level, it can be seen the integrative efforts which are visible in determination of vision, mission, and other policies. The material level includes the curriculum package, using the verses, and the formation of Islamic worldview in the form of a separated course. The level of strategy is more to the ability of the lecturers in integrating the knowledge during the learning process and integration on the methodology side. In this case, the International Islamic University of Malaysia (IIUM) which has implemented it in the form of establishment and implanting the Islamic worldview maximally by providing trainings and guidance of a longterm and continuous to all lecturers, administrative staff, then are introduced to the students continuously with integrated system and mental as well.

\footnotetext{
${ }^{7}$ M. Amin Abdullah, Islamic Studies di PerguruanTinggi; PendekatanIntegratif-interkonektif.Cet. Ke II. (Yogyakarta: PustakaPelajar, 2010), p. Vii-viii.

${ }^{8}$ TIM POKJA, PenerapanTransdisipliner, p. 7.
} 


\section{DISCUSSION}

When IAIN of North Sumatra was established in 1973, its main mission was to serve as an Islamic university institution that transmitted Islamic knowledge in the sense of 'ulûm dîniyyah. Along with the knowledge development and the needs of national development, then in the era of the 1990s, IAIN SU entered a new phase which was characterized by the provision of a wider mandate. Furthermore, entering the era of the 2000s, IAIN SU enters a more developed stage that is not just a wider mandate, but also has to lead to scientific integration. This development was then followed up by the transfer of institutional status of IAIN of North Sumatra to State Islamic University of North Sumatra (Universitas Islam Negeri Sumatera Utara). Furthermore, it is in line with this change that the study of knowledge at IAIN has changed from monodiscipliner to interdisciplinary and transdisciplinary. ${ }^{9}$

Epistemologically, the scientific integration model applied in UIN SU is a combinative integration in which the living system is used as the master paradigm, that is: expanding ideas and simplifying the process of combining different kinds of knowledge into one container. In this perspective, the relationship of science and religion is no longer a concernedtopic, but how the religious concepts contribute to the production of integrative new knowledge. ${ }^{10}$

In the context of reintegration of Islamic studies with non-Islamic studies, M. Amin Abdullah says that according to the study of philosophy of knowledge, almost all types of educational activities, both natural and social knowledge, even religious knowledge, always experience what is called shifting paradigm (shifting cluster of knowledge paradigm). The knowledge activities will forever be historical, because they are built, designed, and formulated by the human mind that is historical as well. What is meant by being historical is bound by space and time, influenced by the development of thinking and development of social life that surrounds a certain time. Thus, it is possible that there are changes, shifts, improvements, reformulation, nasikh and mansukh, and the improvement of the design of knowledge epistemology. ${ }^{11}$

Thus, the vision and mission of knowledge in UIN SU has also been changed, in accordance with the changes and the development of present social life. From a paradigm point of view, UIN SU uses the living system as a paradigm master, which aims to expand ideas and simplifies the process of combining different kinds of knowledge into one container. The establishment of a holistic living system as a philosophical foundation of integrative knowledge in UIN SU departs from the essence of Islamic studies that are built on the foundation of the doctrine of monotheism, which in many ways corresponds to the philosophy of living system. At the very least, the principles of living systems open up the space to produce totalistic knowledge that includes spiritual things and divine essence in their knowledge buildings. ${ }^{12}$

The living system is an ancient idea used by poets, philosophers and musicians to convey the feelings of attachment and interdependence of all phenomena. Then, this tradition of thinking system was developed by James Grier Miller and Fritjof Capra in the early 20th century to form the conceptual and historical roots of a new scientific framework. ${ }^{13}$

The researcher's analysis toward this theory, the most fundamental thing that can be taken from the thinking system of living system is the participation of all parts and the continuous negotiation among the interests at all levels of the organization. The connection with the knowledge integration means how to realize the knowledge of all fields in this universe - at all levels - participate and negotiate in order to provide the greatest benefit to life, as the purpose of the creation of human beings, in order to become God's servant who are capable to manage and to prosperthe universe, as a manifestation of ayatkhairaummatinukhrijat li annâsta`murûna bi al-ma'rûfwatanhauna 'an al-munkarwatu`minûna bi Allâh.

Another principle is that human is a living system in a larger living system than our earth. In this case, the relationshipto the context of knowledge integration, talking about knowledge means the actor is human. Human as a living system that is bigger and his problem is more complex than the earth, must be understood integrated holistically, including the development of science and knowledge in itself, for the realization of humanity as a whole.

The vision, mission, goals, and targets of IAIN SU conversion into UIN SU that the researcher assesses also have gained the integration efforts as follows:

\footnotetext{
${ }^{9}$ Nur Ahmad FadhilLubis, kata PengantardalamBukuPenerapanTransdsipliner di UIN Sumatera Utara. (Medan: Tim PokjaAkademik, 2015), p. i.

${ }^{10}$ TIM POKJA AKADEMIK PIU-IsDB, PenerapanTransdisiplenr di UIN Sumatera Utara.(Medan: UINSU Press, 2015), p. 58.

${ }^{11}$ Ibid.

${ }^{12}$ Tim POKJA Akademik PIU-IsDB, PenerapanTransdisipliner di UIN Sumatera Utara.(Medan: POKJA AKADEMIK PIU-IsDB UIN, 2015). p. 58

${ }^{13}$ Ibid.,p. 27.
} 
Vision: in 2025 the State Islamic University of North Sumatra becomesa barometer of the development of integratedIslamic Sciences and concern on the development of theories, methods, and technology of community empowerment.

Mission: to realize the vision, UIN SU will carry out the following mission;

a. Undertaking the knowledge integration between general and religious studies from 2014-2025.

b. Applying the foundation of integrative philosophical knowledge in studying and developing knowledge, culture, and civilization of mankind, especially Muslims.

c. Strengthening Islamic higher education in Indonesia as a center of excellence Science and Technology, culture, and civilization, as well as providing axiological and moral foundation for the Science and Technology utilization.

d. Developing explorative, explanative, experimental, and developmentative research in various fields of knowledge based on integrative knowledge philosophy.

e. Creating and developing an integrative knowledge-based civil society to enhance the capacity and the empowerment in various aspects of humanity, knowledge, Islamic life and Indonesianess. ${ }^{14}$

To achieve the above vision and mission, then the purpose of conversion of IAIN SU to UIN SU is implemented with the following objectives:

a. Producing the integrative knowledge at the epistemological level, curriculum, and learning materials.

b. Realizing the philosophical foundation of integrative knowledge in studying and developing the container of managed studies.

c. Producing explorative research, alumni dedication, as a logical consequence of the growing number of faculties and study programs.

d. Increasing the public appreciation on the services provided by the universities, and to meet the increasingly various demands of stakeholders on the role of universities.

e. Developing and preserving the divine and human values, as well as respecting the cultural identity, traditions, and religions that are the wealth heritage of human cultural.

f. Fostering a stronger foundation for developing an authentic and universal human culture based on Islamic values.

g. Developing the education that meets different cultures and traditions in relation to each other, implanting a spirit of diversity/pluralism, and improving human rights to maintain their own identity in mutual creative dialogue. ${ }^{15}$

Target: conversion of IAIN SU to UIN SU is conducted with the targets as follows:

a. The creation of integrative epistemology knowledge on each study program, the compilation of each integrative curriculum, and the elaboration on each syllabus or lecture material.

b. The implementation of the use of philosophical basis in the lecture activities.

c. The publication of scientific papers and research results in integrative knowledge disciplines at the national and international levels.

d. The increasing of public appreciation on services provided by the university, and to meet the increasingly various demands of stakeholders on the role of universities.

e. The improvement and maintenance the values of divinity and humanity, as well as respect for cultural identity, traditions, and religions that are a wealth heritage of human cultural.

f. The fostering of a stronger foundation for the development of an authentic and universal human culture based on Islamic values.

g. The realization of education that meets different cultures and traditions in relation to each other, implanting a spirit of diversity/pluralism, and improving human rights to maintain their own identity in mutual creative dialogue. ${ }^{16}$

\footnotetext{
${ }^{14}$ KelompokKerjaBidangAkademik, Blueprint Universitas Islam Negeri Sumatera Utara. (Medan: UIN press, 2013), p. 9-10.

${ }^{15}$ Ibid.,h. 10-11.

${ }^{16}$ Ibid., h. 10-11.
} 
From the explanation of UIN SU's vision, mission, goals and targets and transformation from IAIN SU to UIN SU, the researcher can see clearly the philosophical and conceptual efforts of the leaders, POKJA Academic Teams and PIUs to realize the integration of knowledge in UIN SU.

The definition of Islamic university and Islamic science is considered very important because it is closely related to every effort to design the curriculum of each study program opened at the university. The view of the knowledge structure within an Islamic university forms an education and learning system. In the later stages, it also affects the material taught and the chosen model of education and learning, this is the influence of educators' perceptions about the Islamic science itself.The curriculum which is developed in UIN SU is a curriculum that integrates knowledge of syar'iyyah with knowledge of non-syar'iyyah (non-revelation, aqliyah, science). Thus, the curriculum which is arranged in each study program within the UIN SU environment should incorporate simultaneously the sciences of syar'iyyah and the non-syar'iyyahknowledge only different in the dominant level. In this context, the study program that focuses on the syar'iyyah knowledge takes its own color by emphasizing the contents of the curriculum which gives more portion to syar'iyyah knowledge, and vice versa, the non syar'iyyah (logics and Science) gives more portion to the non-syar'iyyahknowledge.

In addition, the study program must also include the four levels of knowledge in the curriculum, namely: the normative, philosophical, theoretical, and applicative knowledge. For example, the study program of philosophy, should not only offer philosophical knowledge, but also provide normative, theoretical, and applicative knowledge. Likewise in the study program of religion, it should not only present theoretical and applicative knowledge, but more than that, it should also provide philosophical and normative knowledge.

The results of the interview conducted by the researcher with Mr. Vice Rector I UIN SU, Prof. Dr. SafaruddinSiahaan, M.Pd., who is in charge of academic and scientific, he explained that many concepts or things planned as forms of knowledge integration are still discourses that will be applied in UIN SU. Nevertheless, he also explained that many efforts have been made by UIN North Sumatra to realize the integration of such scholarship.

Starting from the revision of the mindset of lecturers and employees about the ontological status of knowledge, epistemology, hierarchy of science in accordance with Islamic philosophy by conducting many seminars, workshops, and trainings to change or reposition mindset of lecturers and education personnel which is dichotomous and partial to the Integrated one, so that the realization of cooperation between the knowledge and produce a scientist who believes in God, harmful, healthy minded, and balance behaves in looking at life, spouse, universe, treasures, God, children, positions, and so forth.

Some efforts that have been made are seminars and workshops among lecturers and educational staff about the meaning and targets to be achieved in the process of knowledge integration. As a result, there are trainings on making or revising the curriculum, syllabus, and courses that have been applied in IAIN SU, to be modified with integrated curriculum and courses, especially among the knowledge that have been categorized as ulumsyar'Iyyahwhich is integrated with scientific things or values, or vice versa, the knowledge that have been categorized as ulumaqliyyah or ghairusyar'iyyah (science or non-syar'iyyahknowledge) are integrated with the syar'iyyah knowledge, so that between the two are found the intersection that delivers the students to become Muslims ofululalbab.

In addition, the teaching teams are also formed to discuss and formulate the university curriculum for 2015-2016, in which the uniform subjects are considered highly urgent and significant in shaping knowledge integrative models among all UIN SU students, regardless of their faculty and majors. For example, the materials of Alquranshould be the basic material in the first semester, with sub-themes that are suited to the related department. ${ }^{17}$ It means, the researcher found that the chosen verses of Alquranto be the sub themes in the material of Alquran,are not the same, because they must be suited to the relevant departments. Thus, the students in each department have been equipped with using Alquran verse or introduction to Alquranverses which are the basis of the knowledge branches in their respective departments. Thus, they will be imprinted in their minds and souls, thatany knowledge they are involved in, all connected with the Knowledge Owner, Allah SWT, and its usage must also be based on His pleasure. They will be able to conclude that between syar'iyyahknowledge with non-syar'iyyahknowledge has a close relationship.

The examples of faculties that have been widely applied the integration are the faculty of Islamic Economics and Business (FEBI) and the Faculty of Islamic Education, where these two faculties have much accommodated science in the course. Meanwhile the examples of subjects that have got the integration portion are Islamic Sociology, Islamic Psychology, and various other subjects. The faculty of Da'wah and Islamic Communication, the faculty of Ushuluddin and Islamic Studies, the faculty of Syariahand Islamic Law gradually havebegun to accommodate science into the subject contents applied in the faculties.

\footnotetext{
${ }^{17}$ Interview result with MrVice Rector I Universitas Islam Negeri Sumatera Utara, Prof. Dr. Saparuddin, at room of Dean of Tarbiyahfaculty of UIN SU in October 2016.
} 
For example, the course of tafsirat Faculty of Ushuluddin study program Alqur'an and Tafsir (IAT) has appeared more modest and scientifically by presenting thematic tafsir model, 'ilmiy' (scientific, sociological, political, and humanitativetafsir). Besides that, the form of integration at IAT department has also been seen in the selection of students' thesis titles, it fits perfectly with the vision and mission of the department that emphasize the scientific side.

In recent developments or the latest UIN ORTAKER determines that learning in UIN has the principles of Islamic learning society or UIN is expected to produce the graduates who have high learning spirit, in accordance with Islamic teachings that learn or to study a long life education. This is also a part of the principle of integrative educational institutions.If reviewed through the Academic Handbook of UIN SU while comparing it with the Academic Handbook of IAIN SU before it is converted to UIN, there will be many changes, either in the changes of UIN symboland the meanings, rector remarks, course, vision and mission, and all other things that leadto the effort of knowledge integration.For the symbol that uses a curved line forms five angles refer to the five pillars of Islam and Pancasila, which symbolize the integration between Indonesianness and Islamism. While on the symbol of IAIN SU the curved lines that form five angles just symbolize Pancasila. ${ }^{18}$ The blooming flower pattern was chosen to show that UIN SU will continue to grow and to expand, while it is not found in IAIN SU.The image of open Alquranrepresents the foundations of the whole of knowledge in order to further develop and integrate the cues in it with the results of human thought. While in the IAIN symbol, the meaning like this is not found, although the image of the Holy Qur'an is also found.

The very clear of iqra inscribed in Alqur'an means that Islam is the religion that greatly motivates the people to develop knowledge, either through reading and deepening the Alquranverses or kauniyyah verses, to balance the education and the research. In the symbol of IAIN, iqra 'script is not found, and the integrative meaning also does not exist for the symbol of AlquranAlkarim. The image of globe symbolizes the spirit of globalization that the knowledge applied in UIN will be able to produce the generations who are ready to compete globally and lead the world. In the symbol of IAIN, this is not found. The image of cotton and rice symbolize prosperity, that UIN SU has a vision and mission to seek prosperity for all citizens and the general society. As in the previous symbol, the image of two goose feathers in which the angle is meant to symbolize the kowledge. ${ }^{19}$ In terms of the courses distribution, there have been efforts to integrate the scholarship for the enrolled students after IAIN conversion to UIN. So, all students who sit in first semester faculty and any department have the same course. Among them: Alquran, Hadith, Theology, Pancasila, Arabic, English, Indonesian, Islamic Philosophy. For the subjects of Alquranand Hadith, the verses and hadiststaught are chosen with themes that lead to the specialization of the departments.Then, the Researcher takes the next sample on the Ushuluddin faculty of Alquranand Tafseerstudy program and the faculty of Islamic Economics and Business, to see how far they integrate Alquranverses with kawniyyah verses and scientific discoveries, or also how far the theories of conventional economics are integrated with Alquranverses and hadith which imply the basic principles of Islamic economy.

\section{CONCLUSION}

Alqur'an has an integrative knowledge concept, even explicitly or implicitly the editors of Alqur'an describe about the Islamic epistemology from basic knowledge, ontological status, objects of knowledge, objectives of knowledge, character of knowledge, and integrative knowledge. From various data obtained, it can be seen that from the beginning, there have been efforts or Islamizationphases of knowledge or knowledge integration in Islamic universities in Medan city, although not using Islamization or integration with two models:formalist and substantive. And this is a continuation and refinement of integration efforts that had been pioneered by the founders of these educational institutions.In its current development, the Islamic universities in Medan City, especially UINSU Medan majority are still formalists with various levels; Philosophical, material, and strategic. If the formalist model of knowledge integration is continuously allowed, it will eventually lead to secularism, because the public will come to the conclusion that God, morals, spiritual souls are only in educational institutions which are Islamic labeled. As for educational institutions that are not Islamic labeled, there will be found knowledge that is not Islam, paganism, no God, no morals, and so on, in fact all the knowledge belongs to Allah and comes from Allah, and Allah will keep watch over His servants in any educational institutionsthat he or she gets the knowledge and education.

\footnotetext{
${ }^{18}$ BukuPanduanAkademikUniversitasNegeri Islam Sumatera Utara TahunAkademik 2015-2016. (Medan: UIN SU Press, 2015), p. 9.

${ }^{19} \mathrm{Ibid}$.
} 


\section{REFERENCES}

AlFarabi, Ihsha`u al- 'Ulum, (Mesir: Dar al-Fikr al-`Arabiy, 1949)

Al-Khawarizmi, Muhammad bin Ahmad bin Yusuf. Mafatih al-'Ulum. (Mesir: al- Muniriyyah, 1342)

Abdullah, M. Amin. Studi Agama: Normativitas atau Historisitas?. (Yogyakarta: Pustaka Pelajar, 2011)

Islamic Studies di Perguruan Tinggi; Pendekatan Integratif-Interkonektif. (Yogyakarta: Pustaka Pelajar, 2010)

Iqbal, Muhammad. Moralitas Al-Qur`an; Antara Cita dan Realitas. (Medan: Citapustaka Media Perintis, 2012)

Kartanegara, Mulyadhi. Integrasi Ilmu; Sebuah Rekonstruksi Holistik. (Jakarta: UIN Jakarta Press, 2005)

Shihab, M. Quraish. Membumikan Al-Quran; Fungsi dan Peran Wahyu Dalam Kehidupan Masyarakat. Edisi baru (edisi ke-1). (Bandung: Mizan, 2013) 